\title{
Den danske salme i Amerika
}

\author{
Af Enok Mortensen
}

Overbibliotekaren ved det videnskabelige bibliotek John Crerar Library, dr. Jens Chr. Bay, var bogelsker par excellence. Det var en fornøjelse at se den gamle langelænder lunte ned mellem bogstakkene, der fyldte syv etager i den store skyskraber på Michigan Avenue i Chicago. Her og der kunne han standse og tage en bog af hylden, stryge den nænsomt nedad ryggen og blæse støvet af snittet inden han lukkede den op. Der var kostbare førsteudgaver, sjældne videnskabelige værker og originale håndskrifter. $\mathrm{Og}$ når man så havde set og beundret rariteterne og sad i gæstens stol ved hans skrivebord og fik cigaren tændt - altid med en Tordenskjold tændstik - kunne han se på én over brillerne og kærtegne en gammel slidt salmebog:

»Bøgerne, ja, men min mors salmebog det er den bedste af dem allesammen!«

Lad være, at der er en streg af sentimentalitet $\mathbf{i}$ det, men den danske emigrant har sat umådelig stor pris på den gamle salmebog. Jeg gætter på, at en anselig del af dem, der udvandrede, fik stukket en salmebog med i bagagen; måske ikke biblen, det var for mange af dem en vanskelig og utilgængelig bog, men netop salmebogen, der tit blev den eneste arv, den skønneste skat, de fik med hjemmefra. Måske var det en dåbs- eller konfirmationsgave, og når jeg gennem årene har besøgt syge eller gamle dansk-amerikanere og spurgt, om vi ikke skulle synge en salme, har de næsten altid haft en salmebog ved hånden.

Og salmebogen var oftest Roskilde Konvents fra 1855. Når man talte om »den nye«, var det ikke den fra 1956, men Salmebog for Kirke og Hjem fra 1897. Der fortælles, at en boghandler i Bergen brændte inde med et stor oplag salmebøger, da en ny udgave blev 
Det er almindelig kendt, at et forholdsvis stort antal danske har sluttet sig til »De sidste dages hellige«. I 1850'erne var godt $3 / 4$ af danske udvandrere (2.898 af 3.749) konvertitter til Mormonismen, og omkring 1860 boede næsten 19 pct. af den danske befolkning i USA i Utah. I mange år blev der også holdt danske gudstjenester i et ret stort kapel på selve tempelpladsen i Salt Lake City.

Så sent som i 1910 udkom Sion Sange, der indeholdt danske sange og salmer. Bortset fra J. Nordal Bruns And over ånder er indholdet overvejende tendentiøst. Godt et dusin af salmerne er oversatte fra engelsk, men de øvrige er forfattede af danske Mormoner. I en tidligere udgivet dansk salmebog er der lån bl.a. fra Grundtvig, men dog med omskrivninger, der mildest talt grænser til det chokerende. I Syng med os, både mark og skov findes et vers sålydende:

\author{
Syng med os, hver der elsker Fred, \\ Liv og Lyset i Kærlighed: \\ Derfor vor Josephs Blod udrandt, \\ Derfor han stred og Sejren vandt. \\ O Gud ske Lov! (Mormonsalme nr. 177).
}

I Den signede dag med fryd vi ser står der i Mormonsalmen nr. 161 følgende vers til ære for Josef Smith og hans broder Hyrum:
Nu sagtelig skrid, hver Zions Dag
Med straaler i Krans om Tinde.
Hver Time til Herrens Velbehag
Som Bække i Eng henrinde,
Og yndeligt de sig herligt sno
Om Josephs og Hyrums Minde

Noget barokt virker det da også, at Mormonsalmen nr. 56 begynder med ordene:

\footnotetext{
Profeten Joseph Smith han var en Kæmpe bold -
}

navnlig når man erindrer, at "salmen « blev sunget på melodien til Kong Kristian stod ved højen mast!

Ikke alene Mormonerne, men også de andre såkaldte sekter (ikkelutherske troessamfund) sluttede sig til, eller blev ret hurtigt påvirket af, beslægtede amerikanske troessamfund. Helt anderledes 
trykt; men da han eksporterede dem til norske menigheder i Amerika gik de som varmt brød. Så konservativ har også den danske udvandrer været. Det er det gamle og kendte, man har søgt at bevare. Måske har nogle af de nyere menighedskredse i Canada, der støttes af D.K.U., benyttet Den danske Salmebog (af 1956); men jeg er overbevist om, at ingen danske kirker i Staterne nåede at gøre brug af den inden sprogskiftet og sammenslutningerne med andre lutherske kirkesamfund.

Organisatorisk begyndte den danske kirke i Amerika i 1872 det år Grundtvig endte sit levnedsløb. Budskabet om hans død stod $i$ en sortrandet meddelelse i det allerførste nummer af bladet Kirkelig Samler, udgivet af fire pionerpræster, der nogle uger tidligere havde organiseret en Kirkelig Missionsforening.

Der havde dog været spredte danske menigheder før den tid. Allerede i 1856 var der en dansk kirke i Waupaca i Wisconsin, hvis præst, Martin Frederik Sørensen, var søn af den bekente skolemand og samfundsagitator Rasmus Sørensen. Det var ganske vist en anglikansk menighed, men man benyttede den danske salmebog!

Også Metodister, Adventister og Baptister oprettede omkring midten af det 19. århundrede menigheder blandt dansk-norske mennesker. Baptisten Louis Jørgen Hauge udgav i 1867 en salmebog med titlen Psalmer og aandelige Sange. Det er meget sandsynligt, at bogen, der indeholdt 422 sange og salmer, var den første dansk-norske bog trykt i Amerika. Udgiveren der selv havde oversat eller forfattet en fjerdedel af indholdet har dog næppe været nogen stor digter. I et opråb med det formål at få penge til trykkerivirksomheden skrev han blandt andet:

\footnotetext{
Og vil I, Brødre, tegne Eder?

Een Dollar blot af hver jeg beder, Af Søstrene en Halv vil gaa Saa kan jeg giøre Pressen færdig, Saa den kan blive Guds Børn værdig, Saa kan vi deraf Glæde faae!
}

Så tidligt som i 1742 oprettede Brødrekirken (Herrnhutterne) en koloni i Bethlehem i Pennsylvania, men skønt hundreder af danskere sluttede sig til kolonien, var sproget i menighedsarbejdet hovedsagelig tysk og senere engelsk. Først i det 19. århundrede opstod der brødremenigheder, hvor sproget var dansk. 
var det med den langt større gruppe, der bevarede forbindelsen med den danske folkekirke. Det var ikke tilfældigt, at de føromtalte pionérpræster kaldte deres sammenslutning en missionsforening. Dermed understregede de nemlig, at de ikke ønskede at stifte en ny kirke, men at de betragtede sig som børn af og medlemmer af moderkirken i Danmark.

Derfor klædte præsterne sig også - i modsætning til sekternes udsendinge - i kjole og krave, ved gudstjenester fulgte man omhyggeligt de autoriserede ritualer, og salmebogen fik en stor plads i deres tilværelse. Den forenede kirkes forlag i Blair, Nebraska, sendte flere oplag ud af den danske salmebog og udgav også adskillige sangbøger, navnlig Sangeren (1892), en samling vækkelsessange og salmer, der var meget udbredt og elsket $\mathrm{i}$ indremissionsk prægede kredse. Den grundtvigske fløj af udvandrerkirken stillede med ikke så få sangbøger, der ligesom den danske højskolesangbog også omfattede salmer. Iblandt dem må særlig nævnes Dansk Folkesamfunds Sangbog, redigeret af N. F. S. Grundtvigs søn, præsten F. L. Grundtvig. Bogen udkom i mange oplag og benyttes endnu. Dog må det tilføjes, at mange af sangene blev omskrevet så de kunne synges af dansk-amerikanere. Det er for exempel tilfældet med Hostrups Det som lysner over vangen, hvor linien »Danmarks Unge, er rettet til »I Unge«. Knap så nødvendigt havde det vel været at ændre en anden sang af Hostrup, hvor »skål for dem, som rører op« er læmpet til »leve de, som røre op«, men det er muligt, at det er en koncession til Indre Missions kredse eller måske en indrømmelse overfor amerikansk puritanisme. Linien er dog ført tilbage til den oprindelige ordlyd i den sidste udgave af sangbogen, der udkom i 1931. I forbigående kan det nævnes, at mange også af de folkelige sange er blevet oversatte og har fundet stor udbredelse selv blandt amerikanere i almindelighed gennem $A$ World of Song, der kom i 1941, men som er blevet udsendt i flere oplag senere.

De første lutherske menigheder blandt danskerne i Amerika holdt stort set fast ved dansk sprog til først i trediverne af dette århundrede. Det var navnlig tilfældet med den gruppe, der havde stærk tilknytning til den grundtvigske retning. I Den forenede kirke havde man mindre interesse for folkelige og kulturelle værdier end i Den danske kirke, hvor der blev lagt stor vægt på bevarelsen af modersmålet. Her var en af forkæmperne den utrætte- 
lige F. L. Grundtvig. I sin opfordring til, at der i danske kredse oprettedes en samlende virksomhed under navnet Dansk Folkesamfund, skrev han i 1887:

"Når vi her i Amerika vedbliver at være danske, er det fordi, at vi ikke på nogen bedre måde kan gavne det land, vi tilhører. Det er vor faste overbevisning, at vi netop er de bedste amerikanske borgere, når vi vedbliver at være danske -«.

Men ikke desto mindre fulgte danskerne i Amerika nogenlunde de mønstre, der har karakteriseret alle andre emigrantgrupper: børnene har talt modersmålet $\mathrm{i}$ hjemmet, men i det øjeblik de forlader hjemmet begynder integreringsprocessen - gennem skole, fjernsyn og radio, ved kammeratskaber og indgiftning. Unge danskamerikanere af andet og tredie slægtled har ofte gennemgået en identitetskrise, der for manges vedkommende resulterede i erkendelsen af, at de - trods F. L. Grundtvig og ligesindede - var amerikanere, omend af dansk rod og måske med lige så stor interesse for dansk arv og kultur, men nu udmøntet i deres eget sprog.

Under den første verdenskrig udviklede hadet mod prøjsisk kejservælde sig i den amerikanske nation til voksende antagonisme mod alle fremmede sprog. Langsomt og i grunden modvilligt begyndte man - også i danske kredse - at eksperimentere med enkelte gudstjenester på engelsk.

Men hvad skulle man synge? De fleste præster havde meget lidt kendskab til amerikansk salmesang, og det var derfor naturligt, at der blev gjort tilløb til at oversætte danske salmer. Enkelte salmer var dog allerede blevet oversatte - af en amerikaner! Så tidligt som i 1880 havde en Mary Elizabeth Fellowes oversat Grundtvigs påskesalme Tag det sorte kors fra graven. Hermed følger første og sidste vers:

From the grave that dark cross take!

Plant a lily in its stead!

Blossome at each step awake

In the garden of the dead!

Angel's wing upon our graves

For the pilgrim's broken staves.

From the urn doth Phoenix rise,

Songs of joy supplant our sighs!

Aye the God-man. Yes, 'tis $\mathrm{He!}$

Broke the bonds of death abhorred! 
Christ is risen verily -

Life and Spirit is His Word!

Now our morrow shall be May;

Now our sorrow sinks away;

And while Easter anthems ring

Soars the soul on joyous wing.

Mary E. Fellowes tilhørte den anglikanske kirke. Om hun har haft personlig forbindelse med den danske menighed i Hartford, Connecticut, hvor hun boede, vides ikke; men den kendte præst $\mathrm{i}$ Brooklyn, New York, Rasmus Andersen skriver, at »hun har lagt sig meget efter studiet af det danske sprog «. En anden danskamerikansk præst, Jakob Holm (St. Stefans, Chicago, 1876-81) har øjensynlig opmuntret hende til at arbejde videre med oversættelser. Han har fået en takkeskrivelse fra hende i anledning af, at hun som gave fra »Den grundtvigske Salmefond « har modtaget »Grundtvigs Salme- og Sangværk i fire bind, som hun var meget taknemlig for «. I Kirkelig Samler af April 1881 findes yderligere to af hendes oversættelser. Den ene er Ingemanns Glade Jul, hvor det første vers lyder således:

Gladsome Yule! lovely Yule!

Unseen come the angels beautiful.

They fly, bearing blossoms of Eden down;

Where they see Him, who of God is known

Hidden among us they go.

Den anden er Grundtvigs salme til det kirkelige nytår, hvis første vers følger:

Welcome, God's Year! Welcome hither!

Christmas night when the Saviour came

When the Light out of darkness kindled its flame,

Welcome, New Year! Welcome hither!

Man skal dog endnu længere tilbage for at finde den første engelske oversættelse af en dansk salme. Det er Ingemanns Igennem nat og trangsel, der allerede i $1867 \mathrm{blev}$ oversat af salmedigteren Sabine Baring-Gould (1834-1924). Såvidt jeg ved, blev Mary Fellowes oversættelser aldrig optaget i en salmebog. Metriken er jo også mangelfuld, selvom man iøvrigt forbløffes af hendes forståelse af salmernes indhold. Den engelske digter Baring-Goulds 
oversættelse derimod er blevet meget brugt - ikke alene i danskamerikanske kredse, men den findes i mange amerikanske salmebøger og bruges flittigt. Det første vers lyder således:

\author{
Thro' the night of doubt and sorrow \\ Onward goes the pilgrim band, \\ Singing songs of expectation, \\ Marching to the Promised Land. \\ Clear before us, thro' the darkness \\ Gleams and burns the guiding light. \\ Brother clasps the hand of brother, \\ Stepping fearless thro' the night.
}

Man forstår bedre Sabine Baring-Goulds valg af Ingemanns salme, når man erindre, at det er ham, der har skrevet processionssalmen Onward, Christian Soldier, der vandt stor popularitet, ikke mindst under den første verdenskrig. Det var ikke vanskeligt at identificere den kristne stridsmands kamp mod synd og ondskab med soldatens dyst mod fædrelandets og demokratiets fjender.

Der er ingen tvivl om, at den første verdenskrig fremskyndede sprogskiftet blandt mange etniske grupper i Amerika. Tusinder af unge kom i kontakt med andre nationaliteter og racer. Mange af dem oplevede for første gang en gudstjeneste på et andet sprog end deres modersmål, og hvor forskellige de end var i kraft af kulturbaggrund og traditioner, havde de dog det tilfælles, at de talte engelsk, de var indfødte amerikanere. Ikke underligt, at der var et stigende krav om gudstjenester og kirkelige handlinger på det sprog, der nu mere og mere fornemmedes som deres eget.

De danske kirkesamfund, der havde været delt $\mathrm{i}$ to siden 1894, enedes i 1921 om at stile mod udgivelsen af ritualer og en salmebog på engelsk. Ritualerne kom i 1924, salmebogen Hymnal for Church and Home i 1927. Denne er blevet udvidet og optrykt mange gange, sidst i 1954. Den seneste udgave indeholdt 454 salmer, hvoraf 131 var oversat fra dansk. Der var 9 salmer af Ingemann, 17 af Kingo, 37 af Brorson og 52 af Grundtvig. Men desuden var der et stort antal salmer, der fornemmedes som danske, fordi de var kendte fra den danske salmebog: salmer for exempel af Gerhardt, Claudius og Luther. I nogle tilfælde benyttede man salmer allerede oversatte fra tysk til engelsk af amerikanske lutheranere; men det skete også, at en tysk salme blev oversat fra den danske tekst til engelsk, og enkelte salmer oversat fra engelsk til dansk blev 
nu igen overført fra dansk til engelsk. Et exempel er Du som går ud fra den levende Gud, oversat af Grundtvig fra Montgomerys originale tekst og igen fra dansk til engelsk af S. D. Rodholm.

De flittigste oversættere var de dansk-amerikanske præster P. C. Poulsen, J. C. Aaberg og S. D. Rodholm samt den norsk-amerikanske præst Carl Døving.

Så vidt vides var S. D. Rodholm (1877-1951) den der udgav den første beskedne samling af oversatte salmer. Hymns of the North, der udkom allerede i 1919, indeholdt 26 salmer og sange. Forfatteren betragtede selv oversættelserne som »forsøg « og vedkender sig, at der var »room for improvement «, men han håbede at være i stand til at fortsætte arbejdet, hvad han da også gjorde. Et exempel illustrerer, hvordan han sommetider $\mathrm{i}$ årevis puslede med en oversættelse for at gøre den bedre. Hans første gengivelse af Altid frejdig lyder således:

Go free-hearted if your way

May with God find favor,

Though while here, no happy day

Crowns your best endeavor.

Never fear in darkest hour,

Stars your way shall brighten;

Pray "Our Father", and no power

Can His children frighten.

Fight for what you love, yea, die

Bravely to defend it.

Life you thus will sanctify,

And no death shall end it.

Rodholm selv var dog ikke tilfreds med sin gengivelse, og i 3. udgave af samme hefte (1922) var den kommet til at se sådan ud:

Go with cheer, if on your way

God may look with favor.

Though on earth no happy day

Crowns your best endeavor.

Though black night is everywhere, Fear not, stars will guide you.

With the Lord's own simple prayer

$\mathrm{He}$ is close beside you. 
Give your life to serve and save

All you love and cherish;

Living, then, is not to slave,

Dying not to perish.

Noget bedre var den blevet, men den er stadigvæk stiv og kluntet, og det var han godt klar over. Blandt bjergene af manuskripter $i$ hans efterladenskaber fandt jeg efter hans død følgende version, som jeg antager blev skrevet ca. 1944:

On your way, and go with cheer

Should the road seem endless!

He who walks where God is near

Never cand be friendless.

Stars above the clouds still shine

Through your darkest hour!

In the Lord's own prayer you find

Courage, peace, and power.

Fight for everything you love,

With your life defend it;

Such a life is lived above

All that foils and ends it.

Tilsyneladende er det det tredie vers, der har voldt de største vanskeligheder. Derfor fandtes der også et nyt forsøg:

Let your heart control your life,

Turn your loss to winning,

Then your life is worth the strife,

Death a new beginning.

Rodholms endelige version af Chr. Richardts sang kom i 1945 og findes i hans samling $A$ Sheaf of Song. Nu ser den således ud:

On your way! Be brave and true!

Should the road seem endless.

Walk where God is near and you

Never can be friendless.

Stars above the clouds still shine

Through your darkest hour!

In the Lord's own prayer you find

Courage, peace, and power. 
Live and die for what you love!

Cherish and defend it!

Then you lift your life above

Things that waste and end it.

Rodholm har oversat flere hundrede salmer og sange. Mange af hans folkelige sange og enkelte salmer er nu kendt langt ud over dansk-amerikanske kredse. Hans mange gengivelser af Grundtvigs bibelhistoriske sange publiceredes i årevis i dansk-amerikanske blade, men er aldrig udkommet i bogform. Hermed følger nogle af hans bedst kendte oversættelser:

\section{Et jaevnt og muntert virksomt liv på jord}

Give me a simple life, a merry heart,

And kings may keep their pomp and garments splendid;

Let me in hut or mansion live the part

Of one from worthy ancestors descended,

With eye for things above as God ordained,

Awake to greatness, goodness, truth and beauty,

Yet knowing well the yearnings unattained,

Through knowledge, great achievement, deeds and duty.

A wholesome life like this have I desired

To be my children's aim and aspiration;

And when my soul was from its brooding tired

My childhcod-prayer brought me consolation;

Then from the spirit came this truth to me:

That God's own garden full of joy is growing

On earth, when we will give ourselves to be

The plants of Him from whom all life is flowing.

But we may not expect the ripened fruit

Except through growth, the law of all creation;

In spring we see the green and tender shoot;

In early summer like a revelation,

A burst of glory, flowers bright unfold;

Then through the sunny summer days appearing

The fruit matures for harvest: so the soul

Is only step by step its harvest nearing.

\section{Lovsynger Herren:}

Worship the Lord and remember His kindness,

Sing of His mercy, my soul, and rejoice!

He who forgives thy transgressions and blindness

Heals and redeems what the tempter destroys. 
Crowning thy life by His grace never ending, He will fulfill thy desire for the best; Youth $\mathrm{He}$ renews like the Phoenix ascending Happy and strong from the flames of his nest.

Though we have sinned we were never forsaken; High as from earth to the heavens above, Far as from east to the west, He has taken All our transgressions away in His love.

Like as a father he pities and knows us, Knows we are frail and but few are our days; Gone with the winds like the leaves and the roses Who will remember our name and our place?

He will remember: His children before Him Ever a place in His kingdom shall keep. Bless Him, my soul, with His angels adore Him! His loving kindness is boundless and deep.

\section{I al sin glans nu stråler solen:}

The sun now shines in all its splendor,

The light of life with mercy tender;

Now bright Whitsunday lilies grow

And summer sparkles high and low;

Sweet voices sing of harvest gold

in Jesus' name, a thousand fold.

The peaceful nightingales are filling The summer night with music thrilling, So all that to the Lord belong May sleep in peace and wake with song, May dream anew of Paradise And with God's praise at daylight rise.

It breathes from heaven on the flowers, It whispers homelike in the bowers, A balmy breeze comes to our shore From Paradise, now closed no more, And gently purls the brooklet sweet Of life's clear water at our feet.

This works the spirit still descending And tongues of fire to mortals lending, That broken hearts may yet be healed And truth may be in love revealed In Him, who came from yonder land And has returned to God's right hand. 
Awake, ye voices, deep and ringing, And anthems to the Lord be singing: Your beauties lend, ye varied tongues To praise His name in joyful songs, And ye, His church, with one accord Arise and glorify the Lord.

Rodholms håndelag som oversætter blev mere og mere sikkert med årene, men det er let nok at påpege svagheder. Det kneb sommetider med metriken, og til tider tog pædagogen og teologen magten fra digteren så hans stil blev didaktisk. Nogle af hans arbejder plettes af klicheer og banaliteter, men han havde en rig lyrisk åre, og mange af hans salmer og sange er blevet elskede lige så højt af nye generationer, som originalerne var af ældre slægter blandt udvandrerne.

J. C. Aaberg (1877-1972) var muligvis mindre af en digter og noget tungere i travet end Rodholm. Han var derimod sikrere både i metriken og i rimkunsten. Også han var meget produktiv. Hymnal for Church and Home indeholder ikke mindre end 63 af hans oversatte salmer. Desuden var han en belæst salmeforsker, der i 1945 udgav Hymns and Hymnwriters of Denmark, en noget skematisk lærebog $\mathrm{i}$ dansk salmedigtning. Den indeholder mange af hans oversættelser. Hermed følger smagsprøver fra de tre »store« salmedigtere:

Kingo: Som den gyldne sol frembryder:

Like the golden sun ascending In the darkly clouded sky And on earth its glory spending Until clouds and darkness fly, So my Jesus from the grave From death's dark, abysmal cave, Rose triumphant Easter morning, Brighter than the sun returning.

Thanks, o thanks, to Thee, arisen Lord and God Immanuel, That the foe could not imprison Thee within his hell-dark cell. Thanks that Thou didst meet our foe And his kingdom overthrow, Jubilant my spirit raises New Thy never ending praises. 
Sin and death and every arrow Satan hence may point at me Fall now broken at the narrow Tomb that saw Thy victory; There Thou didst them all destroy Giving me the cup of joy That Thy glorious resurrection Wrought my pardon and protection.

Blessed Jesus, let the Spirit So imbue my heart with grace That I walk by Thy blest merit And no more the way retrace To the vile and miry pit Where I lay condemned, unfit, Till redeemed to life victorious By Thy resurrection glorious.

Brorson: Den yndigste rose:

Now found is the fairest of roses, 'Mongst briars it sweetly reposes; My Jesus so precious and holy Abode among sinners so lowly.

Since man his Creator deserted And wholly his image perverted, The world like a desert was lying And all in transgression were dying.

But God, as His promise had granted, A rose in the desert has planted, Which now is with sweetness endowing The race that in evil was growing.

The world may of all things bereave me, Its thorns may annoy and aggrieve me, The foe may afflictions engender, My Rose I will never surrender.

Grundtvig: Hyggelig, rolig:

Fair beyond telling, Lord, is Thy dwelling, Filled with Thy peace.

Oh, how I languish 
And, in my anguish,

Wait for release,

That I may enter Thy temple, Oh Lord,

With Thee communing in deepest accord!

With Thy compassion,

Lord of salvation,

Naught can compare,

Even the sparrow,

Safe from the arrow.

Rests in Thy care.

And as Thou shieldest the bird in its nest

So let my heart in Thy temple find rest.

Years full splendors,

Which to offenders

Earth may afford,

Never can measure

One day of pleasure

Found with Thee, Lord,

When on the wings of Thy quickening Word

Souls are uplifted and Thou art adored.

Rich in Thy blessing,

Onward progressing

Are now Thy friends,

Strengthen'd in spirit

Each by Thy merit

Upward ascends

Till, when at home in that city of gold,

All shall in wonder Thy presence behold.

P. C. Poulsen (1881-1948) er repræsenteret i Hymnal for Church and Home med ikke mindre end 14 originale salmer og 57 oversættelser. I modsætning til Rodholm og Aaberg, der tilhørte den grundtvigske retning, var Poulsen præst i »den forenede kirke«, der nærmest må betragtes som indre missionsk. Det mærkes da også både $\mathrm{i}$ hans valg af salmer og $\mathrm{i}$ hans sprogbrug. Blandt hans 57 oversættelser i førnævnte samling er der kun 14 salmer af Grundtvig, 13 af Brorson, 6 af Ingemann og 5 af Kingo. De fleste andre er nærmest det, der katalogiseres som »åndelige sange«.

Poulsen havde en ret sikker sprogsans og ordene falder let på tungen, når salmerne synges; men der er noget prosaisk og monotont over hans ordvalg. Når man blader igennem salmebogen, kan 
man næsten skelne hans produkter uden at have set hans signatur. Men langt værre er det dog, når Poulsens pietisme fører ham til forvanskning af en salme, som det efter mit skøn er sket med Grundtvigs påskesalme Tag det sorte kors fra graven. Øjensynlig er han (iøvrigt ligesom Aaberg i dennes gengivelse) bange for Grundtvigs dristige ord om, at med opstandelsen skal korset væk og erstattes med en lilje. Poulsen glatter det ud med at bruge udtrykket "signs of mourning « $i$ stedet for korset. Hermed følger hans oversættelse:

Take away the signs of mourning

Grow white lilies in their stead,

Blooming flowers, graves adorning,

Grace the garden of the dead.

Place, instead of signs of grief,

Angel wings in bright relief,

Palms instead of columns broken,

Words of hope that God has spoken.

Sudden darkness light succeeded

When for us He shed His blood,

Brighter light for us was deeded

When the Victor with us stood.

Now our praises rise on high

'Neath the Easter morning sky

Unto Christ, the resurrected,

Proved to be of God selected.

See the friends of Jesus grieving:

How they wring their hands in woe!

They, although im Him believing,

Saw Him yielding to the foe.

When released from death's sharp throes,

$\mathrm{He}$, the Easter Sun, arose;

They beheld the tomb now broken,

Angels pointing to the token.

"Open, tombs! the saints surrender!

Jesus' voice in dusk of day

Sounds in accent strong, yet tender,

Shedding light upon our way.

$\mathrm{He}$ is calling, but not now:

"Adam, sinner, where art thou?

No, He says with gracious favor:

„Here am I, your risen Savior.* 
Here $\mathrm{He}$ is, the God-man risen,

Broken are the chains of death,

Opened is our gloomy prison,

And His Word is life and breath;

Now a summer morning bright

Dawns on us to end our night;

And, their Easter anthems singing,

Souls their way to Him are winging.

Den fjerde af de første oversættere er den norsk-amerikanske præst Carl Døving (1867-1937). Hymnal for Church and Home har 15 af hans oversættelser, og navnlig to af dem har vundet stor popularitet. Den ene er Grundtvigs version af den gamle dagvise, der her gengives in extenso:

O Day full of grace, which we behold,

Now gently to view ascending;

Thou over the earth thy reign unfold,

Good cheer to all mortals lending,

That children of light in ev'ry clime

May prove that the night is ending!

How blest was that gracious midnight hour,

When God in our flesh was given;

Then flushed the dawn with light and pow'r,

That spread o'er the darkened heaven;

Then rose o'er the world that Sun divine

Which gloom from our hearts hath driven.

Yea, were ev'ry tree endowed with speech,

And ev'ry leaflet singing,

They never with praise His worth could reach,

Though earth with their praise were ringing.

Who fully could praise the Light of life,

Who light to our souls is bringing?

As birds in the morning sing God's praise,

His fatherly love we cherish,

For giving to us this day of grace,

For life that shall never perish.

His church He hath kept these thousand years,

And hungering souls did nourish.

With joy we depart from our fatherland,

Where God our Father is dwelling,

Where ready for us His mansions stand, 
Where heaven with praise is swelling, And there we shall walk in endless light With blest ones His praise forth telling.

Som man vil se, er ovenstående version ikke særlig vellykket. Jeg synes endog den er meget ringe, men nu er salmen jo også af så høj lyrisk kvalitet, at det næsten er umuligt at overføre den til et andet sprog. Hvor fladt falder ikke udtrykket "good cheer« imod Grundtvigs billede af dagen, der bringer os "lyst og fromme«, og hvor pauvert er ikke oversætterens ordforråd, så at han gang på gang må bruge ordet "praise «! Desuden skurrer oversætterens pietisme skarpt mod Grundtvigs bredt favnende folkelighed: »Det kendes på os som lysets børn, at natten hun er nu omme«. Det er noget helt andet end, at vi skal "prove« d.v.s. bevise, at natten er omme. $\mathrm{Og}$ i sidste vers lader oversætteren de hellige vandre $\mathrm{i}$ evigt lys, mens de uafladeligt priser Herren. Også det er et noget andet billede end »med venner $\mathrm{i}$ lys at tale«.

Når denne salme ikke desomindre er blevet sunget meget, må det formenes at være fordi det var en kendt og elsket salme. Både melodi og ord mindede udvandreren om fædrelandet, han havde forladt, såvel som om det himmelske. Døvings oversættelse af Kirken den er et gammelt hus er også blevet meget brugt endog langt ud over danske kredse. Det skyldes måske i nogen måde den majestætiske melodi, men også den ret geniale begyndelseslinie, "Built on a Rock the church doth stand -«. Fejlen er blot, som dr. Johannes Knudsen har påpeget, at Grundtvig jo ikke i denne salme sang om Kristus som hovedhjørnestenen; han beskrev den historiske kirke, og derfor leder begyndelseslinien helt tankerne bort fra det Grundtvig ville sige. Hermed følger oversættelsen:

Built on the Rock the Church doth stand

Even when steeples are falling;

Crumbled have spires in every land,

Bells still are chiming and calling;

Calling the young and old to rest,

But above all the soul distrest,

Longing for rest everlasting.

Surely in temples made with hands

God, the Most High, is not dwelling,

High above earth His temple stands, 
All earthly temples excelling;

Yet, He whom heavens cannot contain

Chose to abide on earth with men -

Built in our bodies His temple.

We are God's house of living stones,

Builded for His habitation;

He through baptismal grace us owns,

Heirs of His wondrous salvation;

Were we but two His name to tell,

Yet, He would deign with us to dwell,

With all His grace and His favor.

Still we our earthly temples rear,

That we may herald His praises;

They are the homes where He draws near

And little children embraces;

Beautiful things in them are said,

God there with us His cov'nant made,

Making us heirs of His kingdom.

Here stands the font before our eyes,

Telling how God did receive us;

Th' altar recalls God's sacrifice

And what His table doth give us;

Here sounds the word that doth proclaim

Christ yesterday, today the same,

Yea, and for aye our Redeemer.

Grant then, $O$ God, where'er men roam,

That when the church bells are ringing,

Many in Jesus' faith may come

Where He His message is bringing:

I know mine own, mine own know me,

$\mathrm{Ye}$, not the world my face shall see:

My peace I leave with you, Amen.

Når man vurderer oversættelserne kritisk bør man dog erindre, at det var menighedernes tarv, der lå oversætterne på hjerte mere end æstetiske og literære hensyn. De var utvivlsomt på det rene med, hvor vanskeligt det var at tillæmpe en dansk salme et andet sprog, og der var næppe nogen af dem, der følte sig som store digtere. Deres hensigt var hovedsagelig at være formidlere af den rige arv, der lå gemt i dansk salmesang, og derfor var det ikke nok, at 
essensen af salmernes indhold blev bevaret, de skulle også kunne synges. Endvidere må det påpeges, at kendsgerningerne tydeligt viser, hvor usikre de følte sig under byrden af deres vanskelige hverv. De er utilfredse med kollegernes gengivelse og lige så kritiske overfor deres egne præstationer. Derfor tøver de heller ikke med at "lappe " på deres egne forsøg, eller med at give sig i lag med en salme, der allerede er oversat af en anden. Der er flere varianter af mange salmer, bl.a. Dejlig er jorden, Altid frejdig, Den store hvide flok o.s.v. Den sidstnævnte salme er oversat både af Aaberg, Rodholm og Døving, og Døving har offentliggjort to forskellige versioner.

I længere tid før de lutherske kirke-sammenslutninger fandt sted (i $1960 \mathrm{og}$ i 1962) var hovedanken mod enhedsbestræbelserne frygten for, at den danske salmetone ville forsvinde i det store hav af amerikanske salmetoner. Det viste sig da også at være begrundet, for da den store fælles salmebog for Lutheranere udkom (allerede i 1958) indeholdt den kun 17 danske salmer (udaf 602). Der var 1 af Brorson, 2 af Birgitte Boye, 2 af Ingemann, 4 af Kingo og 7 af Grundtvig.

Lige så chokerende var det, at man havde ignoreret eller vraget så at sige alle oversættelserne fra Hymnal for Church and Home. Der var to bidrag af Døving, og Aaberg var repræsenteret med et enkelt vers - Kingos Skriv dig, Jesus, på mit hjerte. Der var ingen oversættelser hverken af Poulsen eller af Rodholm - ikke en gang sidstnævntes meget yndede og fortræffeligt oversatte $I$ al sin glans -. Der kan være to grunde til denne tilsidesættelse. Måske fandt man, at oversættelserne sprogligt set var underlødige. For den kritiske salmekomité måtte alle salmer selvsagt stå på egne ben, uden at være afstivede og omgivne af emotionelle og sentimentale hensyn. Sammenligner man i store træk gengivelserne med den store salmedigtning må det da også erkendes, at meget af det var af ringere kvalitet set fra et literært synspunkt. Men noget andet må dog også tages i betragtning: mange af salmerne er så udpræget danske. Det er muligt, at Rodholms gengivelse af Grundtvigs mesterlige lyriske pinsesalme blev vraget netop på grund af de egenskaber, der har gjort salmen så elsket af danske mennesker.

I den danske kirke, der altså i 1958 endnu fungerede organisatorisk, søgte man at udfylde savnet af danske salmer ved at udgive et supplement, der endnu bruges i mange menigheder med dansk 
Worldly greats, our efforts scornir.g,

May reject our humble homes,

Yet the glow of Easter morning

To the faithful richly comes.

In the lap of common people

Jesus laid His infant head,

Asking neither tower nor steeple,

Now He breaks with us His bread.

Great cathedrals tell their story,

Oft of fallen arch and dome,

But the glow of heaven's glory

Lingers in our cottage home.

All the riches we can gather

Cannot match the love of God;

Through His Son, our loving Father

Truly blessed our home, our sod.

Tilsidst skal citeres Knudsens oversættelse af to af Grundtvigs sange - vanskelige at gengive på engelsk, men måske dem, der tydeligst bærer præg af Grundtvigs syn på menneskelivet:

Grundtvig: Udrundne er de gamle dage:

Relentlessly the human story

Moves like a river to the sea.

Our day of days, its growth and glory

Will ne'er abide eternally.

But humankind does yet survive.

God's given image is alive.

For every fray that death is winning,

As worn-out warriors rest their swords,

God grants a new and fresh beginning

To man, created by His word,

And we retain as ages move

The memory of God's great love.

With hope we face the task of living,

The gift, the promise of our life,

Our constant effort ever giving

Against the foe's relentless strife.

Death's claim and power we defy,

God's saving grace gives victory. 
baggrund. Heftet indeholdt 28 salmer, hvoraf de 20 var af Grundtvig. En komité havde revideret de fleste oversættelser i et velment forsøg på at gøre dem bedre. De mange revisioner demonstrerede nye generationers positive, men også berettigede kritik. Man begyndte at omvurdere de gamle oversættelser uden følelsesbetonede forbehold. Dr. Johannes Knudsen har således den indvending mod Rodholms meget benyttede gengivelse af $O$ Kristelighed, at den skildrer »landet« som noget hinsidigt. Endvidere bruger oversætteren udtrykket at »my kingdom is love". Det sagde Grundtvig ikke. Han sagde, at "mit land er himmel og jord, hvor kærlighed bor «.

I de senere år har Johannes Knudsen selv arbejdet med oversættelser. Her følger nogle exempler:

\section{Grundtvig: Tor end nogen ihukomme -:}

Dare we yet recall the tender

Hopeful dreams of years gone by?

Though the world its judgment render,

Can for Zion still we cry?

Can we now, our harps attuning,

Sing a song af ancient days,

Anthems shouting, carols crooning,

Chant, Jerusalem, your praise?

Come, assemble by the mountain,

Zion's daughters, young and old!

They who conquered field and fountain

Zion's hill have not controlled.

Ruined all, by foe's commanding,

We have yet the cornerstone;

All the blows of arms withstanding,

It is firm and it alone.

Ours is not a temple, rearing

Tower and steeple to the sky;

Modest homes are now appearing,

Fruits of what we do and try.

Yet when we in faith have striven

In the shadow of God's wings

With a true foundation given

We can build for better things. 
Grundtvig: Et javnt og muntert virksomt liv på jord:

A plain and active, joyful life on earth,

A treasure, ne'er for power or gold to barter,

A guided life, the nobleness of birth

And equal dignity each human's charter,

A life created, tuned to that above,

Alert to man's God-granted gift of living,

Profoundly mindful of the need for love

Which God, the Father's, grace alone is giving.

A life like this I seek for all mankind.

I plan and work a fruitful growth preparing,

And when the seeking wearies out the mind,

The Lord's own prayer gives me strength and daring.

The Comfort of the Spirit comes to me

That God has blessed our human, frail endeavor,

That in His hand alone our soul is free

And growth will come in nature's way forever.

A life created, tuned to that above!

A plant is rooted, fed by sun and showers,

The growth which reaps the care of nurture's love

Will find its harvest as a seed from flowers.

And though our day of years be short or long,

Creative growth we may to all be giving,

Our faithful efforts all to God belong,

And sunset glory crowns our gift of living.

Ovenstående artikel har søgt at skildre hovedlinierne i det arbejde, der gennem et par snese år er blevet gjort i Amerika for at bevare og videreføre en væsentlig del af dansk ånd og kultur. For et folk, der har måttet opleve et sprogskifte, har det ret anselige udvalg af oversatte salmer og sange været af uvurderlig betydning. Og det er heller ikke umuligt at $i$ alt fald en del af denne danske arv en gang vil vinde en plads også i den amerikanske salmeverden. Men skal det ske, må der arbejdes videre med stoffet af mennesker der, som for exempel Johannes Knudsen, bevæger sig frit både i dansk åndsliv og i amerikansk tankegang, teologi og terminologi.

\section{NOTE}

Denne afhandling fremstiller de forhold, under hvilke Grundtvigs salmedigtning hidtil har kunnet virke i USA. Forfatteren, dr. Enok Mortensen, er født i Danmark, men har levet største delen af sit liv som præst for danske menigheder i USA. Han er ligesom dr. Johannes Knudsen og dr. Ernest D. Nielsen medlem af den komité, der i Amerika er nedsat for at samarbejde med Grundtvig-Selskabet om at udgive et udvalg af Grundtvigs skrifter på engelsk. 